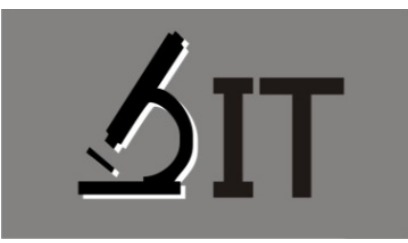

p-ISSN : $2597-8977$

e-ISSN : 2597-8985

Nurhaerani Samudar SMP Negeri 2 Mappadeceng

Ramlawati

Universitas Negeri Makassar

Sudarto

Universitas Negeri Makassar
JIT 3 (1) (2019) 74-83

JURNAL IPA TERPADU

http://ojs.unm.ac.id/index.php/ipaterpadu

\section{PENGARUH MEDIA PUZZLE PADA MODEL PEMBELAJARAN KOOPERATIF TIPE DIVISI PENCAPAIAN KELOMPOK PESERTA DIDIK TERHADAP HASIL BELAJAR IPA PESERTA DIDIK KELAS VIII SMP NEGERI 2 MAPPEDECENG (STUDI PADA MATERI POKOK SISTEM PEREDARAN DARAH MANUSIA) KABUPATEN LUWU UTARA}

Abstrak: Penelitian ini bertujuan untuk mengetahui ada tidaknya pengaruh penggunaan media puzzle pada model pembelajaran kooperatif tipe divisi pencapaian kelompok peerta didik terhadap hasil belajar IPA peserta didik. Metode penelitian yang digunakan adalah eksperimen semu dengan desain penelitian yang digunakan adalah Pretest-Postest Control Group Design. Variabel bebas dalam penelitian ini adalah penggunaan media puzzle pada model pembelajaran kooperatif tipe divisi pencapaian kelompok peserta didik di kelas eksperimen, variabel terikatnya adalah hasil belajar IPA peserta didik pada materi pokok Sistem Peredaran Darah pada Manusia. Populasi penelitian ini adalah peserta didik kelas VIII SMP Negeri 2 Mappedeceng yang terdiri atas 8 kelas dengan jumlah peserta didik 248 orang. Teknik pengambilan sampel yang digunakan acak kelas (cluster random sampling). Kelas yang terpilih sebagai sampel yaitu kelas VIII-3 sebagai kelas eksperimen yang terdiri dari 30 peserta didik dan kelas VIII-4 sebagai kelas kontrol yang terdiri dari 30 peserta didik. Data diperoleh dari tes hasil belajar peserta didik yang terdiri dari 25 butir soal pilihan ganda. Analisis data mengunakan analisis statistik deskriptif dan analisis statistik inferensial. Berdasarkan hasil analisis statistik deskriptif diperoleh peserta didik yang diajar dengan media puzzle lebih tinggi $(\bar{X}=$ $0,511)$ daripada peserta didik yang diajar tanpa media puzzle $(\bar{X}=0.32)$. Sedangkan hasil analisis statistik inferensial yang menggunakan uji pihak kanan dan membuktikan $\mathrm{H}_{0}$ di tolak dan $\mathrm{H}_{1}$ diterima. Pengujian hipotesis yang dilakukan dengan uji-t, menghasilkan $t_{\text {hitung }}(2,55)>t_{\text {tabel }}(2,00)$ pada $\alpha=0,05$. Hal ini berarti $\mathrm{H}_{0}$ ditolak dan $\mathrm{H}_{1}$ diterima. Dengan demikian dapat disimpulkan bahwa ada pengaruh media puzzle pada model pembejaran kooperatif tipe divisi pencapaian kelompok peserta didik terhadap hasil belajar IPA peserta didik studi pada materi pokok Sistem Peredaran Darah Pada Manusia.

Kata Kunci: media puzzle, model pembelajaran kooperatif tipe divisi pencapaian kelompok peserta didik, hasil belajar

Abstract: The aims of this research is to know the effect of puzzle media on cooperative learning model teams achievement division to the student's achievement in grade VIII SMPN 2 Mappedeceng (Study on subject matter The Human Circulatory system). The methodology is quasiexperiment the design research is used Pretest-Postest Control Group 
Design. Independent variable of the research using media puzzle on cooperative learning model teams achievement division to the student's achievement in experiment class, dependent variable is science study result of students in subject matter The Human Circulatory System. The population research is students VIII SMP N 1 Masamba which consist of 8 class of 249 all students. Technique taken sample is used random class clusters sampling. The class was elected sample VIII -3 as a experiment class consist of 30 students and VII -4 as a class control consist of 30 students. Data is collected of a result of study test student consist of 25 question multiple choice. Data analysis use statistical descriptive analysis and statistical inferential analysis. Based on the statistical descriptive analysis student taught to the media puzzle higer $(X=0.511)$ than student taught without media puzzle $(X=0.32)$. While use statistical inferential analysis with right side and prove $\mathrm{H}_{0}$ rejected and $\mathrm{H}_{1}$ accepted. The testing of hypotheses with $t$-test, result $t_{\text {accounting }}(2.55)>t_{\text {table }}(2.00)$ on $\alpha=0,5$. It means $\mathrm{H}_{0}$ rejected and $\mathrm{H}_{1}$ accepted. The conclusions from this research there was effect effect of puzzle media on cooperative learning model teams achievement division to the student's achievement in grade VIII SMPN 2 Mappedeceng in subject matter is the human Circulatory System.

Keywords: Puzzle media, Cooperative learning model teams achievement division, Student's achievement.

\section{PENDAHULUAN}

Bidang pendidikan merupakan salah satu faktor penentu keberhasilan suatu Negara, sehingga upaya perubahan dan pengembangan segala aspek pendidikan sering kali dilakukan untuk meningkatkan mutu pendidikan. Upaya yang dilakukan yakni perbaikan perangkat pendidikan, pengadaan sarana dan prasarana pendidikan, peningkatan kualitas guru, dan pembaharuan pendekatan pembelajaran.

Pembelajaran dikatakan berhasil dan berkualitas apabila seluruhnya atau setidak-tidaknya sebagian besar peserta didik terlibat secara aktif, baik fisik, mental maupun sosial dalam proses pembelajaran, di samping menunjukkan kegairahan belajar yang tinggi, semangat belajar yang besar, dan rasa percaya pada diri sendiri. Berdasarkan hal tersebut di atas, upaya guru dalam mengembangkan keaktifan belajar peserta didik sangatlah penting, sebab keaktifan belajar peserta didik menjadi penentu bagi keberhasilan pembelajaran yang dilaksanakan (Mulyasa, 2004).

Berdasarkan hasil pengamatan yang dilakukan di SMPN 2 MAPPEDECENG, pada tanggal 17 November 2015, menunjukkan bahwa belum terlaksananya kegiatan pembelajaran khususnya pada mata pelajaran IPA yang menyenangkan. Pembelajaran belum berpusat pada peserta didik yang tergambar pada antusias peserta didik yang kurang pada proses pembelajaran. Hal ini berimbas pada rendahnya hasil belajar peserta didik pada mata pelajaran IPA. Pada tahun ajaran. 2014/2015, hasil belajar IPA peserta didik masih banyak belum memenuhi standar KKM, dimana hanya $53 \%$ dari keseluruhan peserta didik kelas VIII yang memenuhi standar KKM. Beberapa penyebab rendahnya hasil belajar peserta didik karena pembelajaran yang belum efektif, dilihat dari kurangnya kerja sama dan saling tukar informasi antar peserta didik. Selain itu, kurangnya penggunaan media pada saat proses pembelajaran menyebabkan peserta didik merasa tidak tertarik sehingga cepat bosan dan sulit memahami materi yang diajarkan. 
Proses pembelajaran IPA akan mendapatkan hasil yang lebih baik apabila pembelajaran tersebut menyenangkan, sehingga peserta didik lebih antusias dalam proses pembelajaran. Pembelajaran yang menyenangkan dapat diperoleh dari penerapan model pembelajaran kooperatif. Melalui pembelajaran kooperatif peserta didik saling bertukar informasi, saling memberikan semangat, bersorak merayakan keberhasilan mereka, membantu teman yang kurang memahami suatu materi dan tujuan akhir dari semua proses itu adalah penguasaan konsep serta prestasi belajar yang memuaskan (Huda, 2009)

Model pembelajaran kooperatif tipe STAD (Student Teams Achievement Division) atau dalam bahasa Indonesia divisi pencapaian kelompok peserta didik pada pembelajaran IPA mampu membuat peserta didik lebih mengerti tentang konsep pada materi yang diajarkan. Karena pada model pembelajaran kooperatif tipe divisi pencapaian kelompok peserta didik ini mampu membimbing peserta didik untuk memecahkan suatu masalah bersama dengan teman kelompoknya dan mengorganisir teman yang berada dalam satu kelompok untuk bisa menyelesaikan tugas-tugas. Pada model pembelajaran ini, peserta didik dikelompokkan secara heterogen. Tujuan pengelompokan secara heterogen adalah untuk mengatasi peserta didik yang kurang memahami materi, bisa bertanya kepada teman kelompoknya yang memahami materi tersebut (Slavin, 2008).

Penggunaan media dalam pembelajaran dapat membuat hal yang bersifat abstrak menjadi lebih konkrit dan membuat suasana belajar yang tidak menarik menjadi menarik. Banyak media pembelajaran yang ada tetapi tidak semua digunakan dengan baik oleh guru. Umumnya, peserta didik menyukai permainan, maka dari itu diperlukan media pembelajaran berupa permainan agar peserta didik lebih antusias selama pembelajaran. Salah satu media yang berupa permainan dan baik untuk digunakan adalah media puzzle.

Media puzzle adalah salah satu media pembelajaran berbentuk gambar. Dengan penggunaan media puzzle peserta didik dilatih berpikir logis, mengembangkan ide, mempermudah pemahaman terhadap materi yang disampaikan serta lebih antusias karena pembelajaran menjadi menyenangkan, tidak membosankan dan meningkatkan hasil belajar peserta didik (Wahyuni, 2010).

Hasil penelitian Kurniawati dkk (2013) menunjukkan adanya peningkatan hasil belajar peserta didik saat menggunakan media puzzle pada saat pembelajaran dengan model divisi pencapaian kelompok peserta didik, karena hasil belajar yang diperoleh melalui diskusi akan lebih melekat kuat pada ingatan peserta didik.

Berdasarkan uraian tersebut, maka peneliti tertarik untuk meneliti masalah yang dihadapi peserta didik pada pelajaran IPA. Masalah ini diangkat sebagai bahan penelitian untuk tugas akhir dengan judul penelitian "Pengaruh Media Puzzle pada Model Pembelajaran Kooperatif Tipe Divisi Pencapaian Kelompok Peserta Didik terhadap Hasil Belajar IPA Peserta Didik Kelas VIII SMP Negeri 2 Mappedeceng pada Materi Pokok Sistem Peredaran Darah Pada Manusia ”.

Tujuan penelitian adalah untuk mengetahui ada tidaknya pengaruh penggunaan media puzzle pada model pembelajaran kooperatif tipe divisi pencapaian kelompok peserta didik terhadap hasil belajar IPA peserta didik kelas VIII pada materi pokok sistem peredaran darah pada manusia di SMP Negeri 2 Mappedeceng.

\section{METODE}

Penelitian yang akan dilakukan termasuk jenis penelitian eksperimen semu dengan PretestPosttest Control Group Design. Populasi dalam penelitian ini adalah seluruh kelas VIII SMP Negeri 2 Mappedeceng tahun pelajaran 2016/2017 yang terdiri atas delapan kelas. Pengambilan sampel dilakukan secara acak kelas (cluster random sampling) untuk menentukan kelas eksperimen dan kelas kontrol. Dari delapan kelas diperoleh dua kelas, yaitu kelas $\mathrm{VIII}_{3}$ sebagai kelas eksperimen dan kelas $\mathrm{VIII}_{4}$ sebagai kelas kontrol. 
Instrumen yang digunakan adalah tes pilihan ganda yang terdiri dari 25 butir soal pilihan ganda dengan 3 indikator yang telah divalidasi isi. Tes ini didasarkan pada aspek kognitif meliputi jenjang menginat ( $\left.C_{1}\right)$, memahami (C2), dan Mengaplikasikan ( $\left.C_{3}\right)$ dengan skor masing-masing 1.

Pengumpulan data dalam penelitian ini dilakukan dengan memberikan tes awal (pretest) dan tes akhir (posttest) untuk mengetahui hasil belajar peserta didik. Soal pretest dan posttest yang diberikan sama untuk masing-masing kelas eksperimen dan kelas kontrol. Teknik pengumpulan data dengan menggunakan $\mathrm{N}$-Gain. Skor yang didapatkan selanjutnya diubah ke $\mathrm{N}$ Gain, N-Gain menunjukkan peningkatan hasil belajar peserta didik setelah pembelajaran dilakukan. Penggunaan N-Gain bertujuan untuk menghindari hasil kesimpulan yang akan menimbulkan bias penelitian, karena nilai pretest dari kedua kelompok penelitian sudah berbeda.

Data yang diperoleh dari hasil penelitian ini diolah dan dianalisis dengan menggunakan analisis statistik deskriptif dan analisis statistik inferensial. Analisis statistik deskriptif untuk menggambarkan hasil belajar peserta didik terhadap pelajaran IPA Terpadu yang diperoleh setelah mengikuti pembelajaran. Analisis ini meliputi nilai tertinggi, nilai terendah, nilai rata-rata, dan standar deviasi. Data yang diperoleh selanjutnya dikategorikan dalam kategori tuntas dan tidak tuntas. Analisis deskriptif selanjutkan adalah $\mathrm{N}$-gain untuk melihat peningkatan dari pretest ke posttest. $\mathrm{N}$-Gain adalah perbandingan antara selisih skor posttest-skor pretest dengan selisih skor maksimum skor pretest. $\mathrm{N}$-Gain disebut juga skor gain ternormalisasi.

$$
\mathrm{N} \text {-Gain }=\frac{\text { Skor } \text { posttest }- \text { Skor pretest }}{\text { skor maksimum }- \text { skor pretest }}
$$

Analisis statistik inferensial adalah teknik statistik yang digunakan untuk menganalisis data sampel dan hasilnya diberlakukan untuk populasi (Sugiyono, 2011). Statistik inferensial digunakan untuk menguji hipotesis penelitian dengan menggunakan uji-t. Sebelum menguji hipotesis, terlebih dahulu dilakukan uji prasyarat yang meliputi uji normalitas dan uji homogenitas.

\section{HASIL DAN PEMBAHASAN}

\section{Hasil Penelitian}

Adapun gambaran skor hasil belajar IPA peserta didik kelas eksperimen yang diajar dengan menggunakan media puzzle pada model pembelajaran kooperatif tipe divisi pencapaian kelompok peserta didik dan kelas kontrol yang diajar tanpa media puzzle pada model pembelajaran kooperatif tipe divisi pencapaian kelompok peserta didik adalah sebagai berikut dengan skor maksimal yakni 25 .

Tabel 1. Hasil Belajar IPA Peserta Didik Kelas Eksperimen dan Kelas Kontrol

\begin{tabular}{lcc}
\hline \multicolumn{1}{c}{ Statistik } & $\begin{array}{c}\text { Hasil Belajar } \\
\text { Kelas Eksperimen }\end{array}$ & $\begin{array}{c}\text { Hasil Belajar } \\
\text { Kelas Kontrol }\end{array}$ \\
\hline Jumlah Sampel & 30 & 30 \\
Nilai tertinggi & 25 & 23 \\
Nilai terendah & 14 & 8 \\
Nilai rata-rata & 19,97 & 14,57 \\
Standar deviasi & 3,17 & 3,80 \\
Varians & 10,03 & 14,39 \\
\hline
\end{tabular}

Untuk hasil belajar IPA peserta didik kelas kontrol yang diajar tanpa media puzzle pada model pembelajaran kooperatif tipe divisi pencapaian kelompok peserta didik menunjukkan 
bahwa skor tertinggi yang dicapai adalah 23, skor terendah 8, sedangkan skor rata-rata yang dicapai adalah 14,57. Tabel 4.1 menunjukkan bahwa nilai rata-rata kelas eksperimen yang diajar dengan menggunakan media puzzle pada model pembelajaran kooperatif tipe divisi pencapaian kelompok peserta didik lebih besar daripada kelas kontrol yang diajar tanpa media puzzle pada model pembelajaran kooperatif tipe divisi pencapaian kelompok peserta didik.

Berdasarkan Tabel 2 terlihat bahwa terdapat perbedaan hasil persentase pencapaian indikator pemahaman konsep pada kelas eksperimen dan kelas kontrol. Pencapaian indikator yang paling tinggi pada kelas eksperimen adalah pada indikator menjelaskan macam organ penyusun sistem peredaran darah pada manusia, sedangkan pencapaian indikator yang paling tinggi pada kelas kontrol adalah menjelaskan macam organ penyusun sistem peredaran darah pada manusia. Pencapaian indikator yang paling rendah pada kelas eksperimen adalah menjelaskan fungsi jantung, pembuluh darah dan darah dalam sistem peredaran darah pencapaian indikator yang paling rendah pada kelas kontrol adalah pencapaian indikator menjelaskan fungsi jantung, pembuluh darah dan darah dalam sistem peredaran darah. Persentase rata-rata pemahaman peserta didik pada materi sistem peredaran darah pada manusia pada kelas eksperimen adalah sebesar $82,12 \%$ dan kelas kontrol sebesar $60,58 \%$.

Adapun Persentase Pencapaian Tiap Indikator Kelas Eksperimen dan Kontrol terdapat pada Tabel 2.

Tabel 2. Persentase Pencapaian Tiap Indikator Kelas Eksperimen dan Kelas Kontrol

\begin{tabular}{llccc}
\hline No Indikator & Nomor Soal & \multicolumn{2}{c}{$\begin{array}{c}\text { Kelas } \\
\text { Eksperimen }\end{array}$} & $\begin{array}{c}\text { Kelas } \\
\text { Kontrol }\end{array}$ \\
\hline 1. & $\begin{array}{l}\text { Menjelaskan macam organ } \\
\text { penyusun sistem peredaran } \\
\text { darah pada manusia. }\end{array}$ & $1,2,4,5,21$ & 88,00 & 68,00 \\
2. & $\begin{array}{l}\text { Menjelaskan fungsi jantung, } \\
\text { pembuluh darah dan darah } \\
\text { dalam sistem peredaran darah. }\end{array}$ & $\begin{array}{c}3,6,7, \\
9,10,11,1213,14,15, \\
16,18,20,22,24,25\end{array}$ & 77,00 & 54,00 \\
3. & & & \\
$\begin{array}{l}\text { Menyebutkan contoh penyakit } \\
\text { yang berhubungan dengan } \\
\text { sistem peredaran darah yang } \\
\text { biasa dijumpai dalam kehidupan } \\
\text { sehari-hari dan upaya } \\
\text { mengatasinya. }\end{array}$ & $8,17,19$, & 81,00 & 60,00 \\
\hline & & & \\
\hline Rata-Rata & $\mathbf{8 1 , 1 2}$ & $\mathbf{6 0 , 5 8}$ \\
\hline
\end{tabular}

Adapun gambaran tentang persentase hasil belajar IPA yang disusun baik pada kelas eksperimen maupun kelas kontrol ditampilkan pada gambar berikut ini.

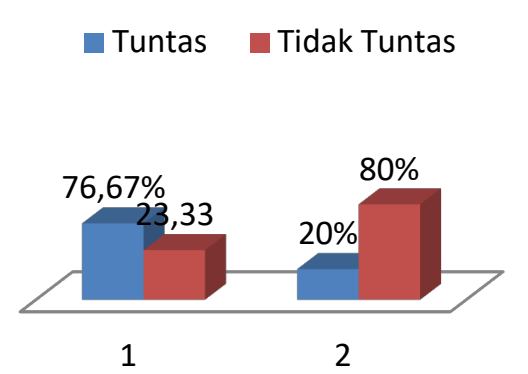

Gambar 1. Kriteria Ketuntasan Hasil Belajar IPA Peserta Didik pada Kelas Eksperimen dan Kelas Kontrol 
Berdasarkan Gambar 1 terlihat bahwa kelas eksperimen presentase 76,67\% ketuntasan peserta didik dan $23,33 \%$ ketidak tuntasan peserta didik sedangkan pada kelas kontrol memiliki persentase $20 \%$ pada kategori Ketuntasan peserta didik dan $80 \%$ pada ketidak tuntasan peserta didik.

Perhitungan N-gain untuk hasil belajar IPA peserta didik pada kelas eksperimen dan kelas kontrol dapat dilihat pada Tabel 3. Pengumpulan data hasil penelitian untuk hasil belajar IPA dilakukan menggunakan alat pengumpul data berupa tes pilihan ganda.

Tabel 3. Klasifikasi, frekuensi dan persentasi N-Gain hasil belajar IPA peserta didik pada kelas eksperimen dan kelas eksperimen kontrol

\begin{tabular}{|c|c|c|c|c|c|}
\hline \multirow[b]{2}{*}{ Kelas } & \multirow[b]{2}{*}{$\mathbf{N}$} & \multicolumn{2}{|c|}{ Skor } & \multirow[b]{2}{*}{ Rata-rata N-Gain } & \multirow[b]{2}{*}{ Kategori N-Gain } \\
\hline & & Terendah & Tertinggi & & \\
\hline Eksperimen & 30 & 0 & 1 & 0,511 & Sedang \\
\hline Kontrol & 30 & 0 & 0,8 & 0,32 & Sedang \\
\hline
\end{tabular}

Berdasarkan Tabel 3, data yang diperoleh skor terendah pada kelas eksperimen dan pada kelas kontrol adalah o. Skor Tertinggi pada kelas eksperimen adalah 1 sedangkan pada kelas kontrol adalah 0,8. Skor rata-rata $\mathrm{N}$-Gain pada kelas eksperimen adalah 0,511 sedangkan pada kelas kontrol adalah 0,32. Maka dapat disimpulkan bahwa N-Gain pada kelas eksperimen lebih tinggi dibandingkan dengan $\mathrm{N}$-Gain pada kelas kontrol.

Uji normalitas yang digunakan dalam penelitian ini adalah chi kuadrat. Berdasarkan hasil perhitungan untuk kelas eksperimen yang diajar menggunakan media puzzle diperoleh $\chi^{2}$ hitung $=$ 9,94. Untuk $\alpha=0.05$ dan $\mathrm{dk}=\mathrm{k}-1=6-1=5$, maka diperoleh $\chi_{\text {tabel }}^{2}=\chi_{(0,95)(5)}{ }^{2}=11,07$. Dengan demikian $\chi^{2}$ hitung $<\chi_{\text {tabel }}^{2}(9,94<11,07)$ yang berarti skor hasil belajar IPA peserta didik berasal dari populasi yang berdistribusi normal. Demikian pula halnya dengan kelas kontrol yang diajar tanpa menggunakan media puzzle diperoleh $\chi_{\text {hitung }}^{2}=10,61$. Untuk $\alpha=0.05$ dan $\mathrm{dk}=\mathrm{k}-1=6-1=5$, maka diperoleh $\chi_{\text {tabel }}^{2}=\chi_{(0,95)(5)}^{2}=11,07$. Dengan demikian $\chi_{\text {hitung }}^{2} \chi_{\text {tabel }}^{2}(10,61<11,07)$ yang berarti skor hasil belajar IPA peserta didik berasal dari populasi yang berdistribusi normal.

Berdasarkan hasil pengujian normalitas, ternyata data diperoleh dari populasi yang berdistribusi normal, maka dilanjutkan dengan uji homogenitas varians populasi. Berdasarkan analisis dengan taraf nyata $\alpha=0,05$ diperoleh nilai $F_{\text {hitung }}$ dan $F_{\text {tabel }}$ untuk hasil belajar IPA, $F_{\text {hitung }}=$ 1,45 dengan $F_{\text {tabel }}=1,84$. Karena $F_{\text {hitung }}<F_{\text {tabel }}$ hal ini menunjukkan bahwa data dalam penelitian ini termasuk homogen.

Berdasarkan hasil uji prasyarat bahwa data berdistribusi normal dan homogen, maka selanjutnya data dianalisis untuk pengujian hipotesis menggunakan uji-t. Pengujian hipotesis penelitian ini menggunakan uji satu pihak dengan uji-t sehingga diperoleh nilai $t_{\text {hitung }}$ untuk hasil belajar IPA peserta didik sebesar 2,55 sedangkan $t_{\text {tabel }}$ adalah sebesar 2,00. Dimana $t_{\text {tabel }}=2,00<$ $t_{\text {hitung }}=2,55$. Hal ini berarti hipotesis nol $\left(\mathrm{H}_{0}\right)$ ditolak dan $\mathrm{H}_{1}$ diterima.

\section{PEMBAHASAN}

Berdasarkan hasil penelitian yang telah di SMP Negeri 2 Mappedeceng menunjukkan bahwa penggunaan media puzzle pada model pembelajaran kooperatif tipe divisi pencapaian kelompok peserta didik dapat memperngaruhi hasil belajar IPA peserta didik. Proses penelitian dimulai dari mengetahui kemampuan awal peserta didik dengan melakukan pretest sebelum diberikan perlakuan pada kelas eksperimen berupa penggunaan puzzle pada model pembelajaran 
kooperatif tipe divisi pencapaian kelompok peserta didik dan pada kelas kontrol tanpa perlakuan . Pretest diberikan kepada kedua kelas baik kelas eksperimen maupun kontrol berupa 25 butir soal pilihan ganda.

Berdasarkan data pretest menunjukkan rat-rata kelas eksperimen lebih tinggi dibandingkan dengan kontrol. Hal tersebut menunjukkan bahwa kelas eksperimen lebih baik daripada nilai awal kelas kontrol, tetapi rata-rata nilai eksperimen dan kelas eksperimen masih rendah. Hal ini dikarenakan materi yang di ujikan belum diajarkan kepada peserta didik, jadi mereka menjawab pertanyaan sesuai dengan pengalaman peserta didik dalam kehidupan sehari-hari.

Setelah pretest dilaksanakan, kemudian kedua kelas tersebut menjalankan proses belajar mengajar. Pembelajaran pada kelas eksperimen (diberikan perlakuan dengan penggunaan media puzzle pada model pembelajaran kooperatif tipe divisi pencapaian kelompok peserta didik sedangkan kelas kontrol tanpa perlakuan namun menggunakan model pembelajaran kooperatif tipe divisi pencapaian kelompok peserta didik. Setelah selesai dalam proses pembelajaran yang telah diberikan perlakuan, kegiatan berikutnya ialah diadakannya posttest. Posttest dilakukan untuk mengetahui hasil belajar pada aspek kognitif pada materi sistem peredaran darah pada manusia berupa 25 butir soal pilihan ganda.

Pada data posttest terdapat perbedaan hasil belajar antara kelas eksperimen dan kelas kontrol disebabkan karena kelas eksperimen menggunakan media puzzle sedangkan pada kelas control tanpa peggunaan media puzzle, dimana dalam pembelajaran peserta didik lebih antusias dan mencari sendiri sehingga termotivasi untuk belajar. Selain itu peserta didik diberi kesempatan untuk berpartisipasi dalam pembelajaran dan guru hanya membimbing peserta didik. Sedangkan kelas kontrol dalam pembelajaran tanpa menggunakan media puzzle dimana guru yang melakukan, menunjukkan dan memperlihatkan suatu proses, sehingga peserta didik bersifat pasif dan kurang termotivasi selama pembelajaran.

Presentase ketuntasan hasil belajar peserta didik kelas eksperimen lebih besar tiga kali lipat dibandingkan kelas kontrol. $\mathrm{N}$-Gain kelas eksperimen yang berada di kategori tinggi jauh lebih tinggi dibandingkan dengan kelas eksperimen kontrol. Pada kategori sedang presentase kelas kontrol lebih tinggi dibandingkan kelas eksperimen, sedangkan pada kategori rendah presentasi kelas kontrol lebih tinggi dibandingkan kelas eksperimen. Adanya peserta didik yang tidak tuntas pada kelas eksperimen dan tuntas pada kelas kontrol meskipun tanpa penggunaan media puzzle, karena terlepas dari proses pembelajaran yang dirancang oleh guru setiap peserta didik memiiki karakteristik yang berbeda-beda. Peserta didik memiliki cara yang berbeda dalam menerima, merespon, mengolah informasi dan menyusunnya berdasarkan pengalaman-pengalaman yang dialaminya terhadap situasi belajar. Perbedaan ini bukanlah suatu tingkatan keterampilan seseorang namun suatu bentuk keterampilan individu dalam memproses dan menyusun informasi serta cara individu untuk tanggap terhadap stimulus yang ada dilingkungannya. Hal ini sejalan dengan yang dikemukakan Sudirman (2007) bahwa setiap individu memiliki perbedaan cara dalam menerima informasi, memproses dan mengorganisasikan kegiatannya, dengan demikian perbedaan tersebut akan mempegaruhi kuantitas serta kualitas kegiatan yang dilakukan termasuk kegiatan yang dilakukan peserta didik dalam pembelajaran di sekolah.

Untuk memperkuat hasil analisis deskriptif di atas, maka dilakukan analisis inferensial untuk membuktikan hipotesis yang diajukan. Sebelum melakukan uji-t, data harus berasal dari populasi yang terdistribusi normal dan homogen. Dari hasil pengujian yang dilakukan dengan menggunakan uji normalitas dan uji homogenitas diperoleh hasil belajar IPA dari dua kelas berasal dari populasi berdistribusi normal dan homogen, sehingga pengujian hipotesis dapat dilakukan dengan menggunakan uji-t.

Setelah semua data dinyatakan normal dan homogen, kemudian di lakukan uji hipotesis dan dilakukan uji-t, didapatkan bahwa $t_{\text {hitung }}>t_{\text {tabel }}$ sehingga $H_{0}$ ditolak dan $H_{1}$ diterima, hal ini menunjukkan bahwa ada pengaruh media puzzle pada model pembelajaran kooperatif tipe divisi pencapaian kelompok peserta didik terhadap hasil belajar IPA peserta didik. 
Pada kelas eksperimen menggunakan media puzzle dimana peserta didik lebih aktif dalam pembelajaran, serta meningkatkan rasa ingin tahu peserta didik tentang pembelajaran yang dilakukan. Hal ini didukung oleh penelitian Diana (2013) menyatakan bahwa penggunaan media puzzle pada model pembelajaran kooperatif tipe divisi pencapaian kelompok peserta didik ternyata mampu meningkatkan aktivitas, perhatian, dan motivasi peserta didik dalam pembelajaran. Karena media puzzle sebagai media berbasis permainan dan visual dapat membangkitkan semangat peserta didik untuk melakukan sesuatu, dalam hal ini peserta didik dilatih keterampilannya dalam merangkai puzzle menjadi gambar yang utuh, sehingga dengan keterampilan dan ketelitian dari peserta didik dapat membangkitkan motivasi belajar yang pada akhirnya akan mendorong peserta didik untuk lebih memahami materi pelajaran sehingga dapat meningkatkan hasil belajar. Selain itu Isjoni (2010) mengemukakan bahwa pembelajaran kooperatif tipe divisi pencapaia kelompok peserta didik merupakan salah satu tipe kooperatif yang menekankan pembelajaran pada adanya aktivitas dan interaksi diantara siswa untuk saling memotivasi dan saling membantu dalam menguasai materi pelajaran guna mencapai prestasi yang maksimal. Pada saat guru menyajikan pembelajaran IPA menggunakan media puzzle pada pembelajaran kooperatif tipe divisi pencapaian kelompok peserta didik terhadap hasil belajar IPA peserta didik akan belajar mengamati, mencoba, mengolah data atau menganalisis data, dan menkomunikasikan hasil pengamatan dan analisisnya". Jadi dapat dikatakan bahwa proses pembelajaran dengan bantuan media puzzle pada pemebelajaran kooperatif tipe divisi pencapaian kelompok peserta didik berperan dalam hasil belajar IPA peserta didik kelas VIII SMP Negeri 2 Mappedeceng.

Dari fakta di atas, mengindikasikan bahwa pada proses pembelajaran kurang maksimal jika peserta didik hanya pada proses pemantapan materi saja, maka dengan pembelajaran berbantuan media puzzle dapat memberikan kesempatan kepada peserta didik untuk aktif dalam mencari, menemukan, menggali dan mengolah pengetahuannya sendiri. Berdasarkan pengamatan selama proses pembelajaran berlangsung bahwa suasana pembelajaran terlihat pada kelas eksperimen lebih semangat dibandingkan pada kelas kontrol. Puzzle yang diberikan oleh guru pada saat proses pembelajaran membuat peserta didik termotivasi dan semangat untuk belajar sehingga konsentrasi peserta didik pada kelas eksperimen terpusat penuh pada pembelajaran. Lain halnya pada kelas kontrol selama proses pembelajaran sebagaian besar peserta didik tidak terfokus pada pembelajaran dan kurang antusias. Di sisi lain peserta didik pada kelas eksperimen mendapat pengalaman belajar yang baru dengan mengggunakan media puzzle pada pembelajaran kooperatif tipe divisi pwncapaian kelompok peserta didik selama proses pembelajaran.

Berdasarkan pembahasan diatas, dapat disimpulkan bahwa terdapat pwngaruh media puzzle pada model pembelajaran kooperatif tipe divisi pencapaian kelompok peserta didik. Hal ini sesuai dengan penelitian sebelumnya yang dilakukan oleh Apriliani (2013) yang juga menunjukkan bahwa pengaruh media puzzle terhadap hasil belajar kimia peserta didik pada materi pokok koloid.

\section{KESIMPULAN}

Berdasarkan hasil analisis data penelitian dan pembahasan dapat disimpulkan bahwa: (1) hasil belajar IPA peserta didik kelas VIII 4 SMPN 2 Mappedeceng Tahun Ajaran 2016/2017 yang dibelajarkan menggunakan media puzzle dalam model pembelajaran kooperatif tipe divisi pencapaian kelompok peserta didik memperoleh rata-rata $\mathrm{N}$-Gain sebesar 0,511 yang berada pada kategori sedang; (2) hasil belajar IPA peserta didik kelas VIII ${ }_{3}$ SMPN 2 Mappedeceng Tahun Ajaran 2016/2017 yang dibelajarkan tanpa menggunakan media puzzle dalam model pembelajaran kooperatif tipe divisi pencapaian kelmpok peserta didik memperoleh rata-rata N-Gain sebesar 0,32 yang berada pada kategori sedang; (3) ada pengaruh penggunaan media puzzle dalam model pembelajaran kooperatif tipe divisi pencapaian kelompok peserta didik terhadap hasil belajar IPA peserta didik pada kelas VIII SMPN 2 Mappedeceng Tahun Ajaran 2016/2017. 


\section{DAFTAR PUSTAKA}

Apriliani, Dewi. 2013. Pengaruh Penggunaan Media Puzzle Dalam Penerapan Model Pembelajaran Kooperatif Tipe Students Team Achievement And Division (STAD) Terhadap Hasil Belajar Kimia Pokok Bahasan Koloid Kelas XI Semester II MAN Mataram Tahun Ajaran 2012/2013. Mataram. Tidak dipublikasikan

Arikunto, S. 2009. Prosedur Penelitian Suatu Pendekatan Praktek. Bandung: Rineka Cipta.

Arsyad, 2013. Media Pembelajaran. Jakarta: Raja Grafindo.

Basuki, W dan Mukti, F. 2001. Media Pengajaran. Bandung: CV.Maulana.

Chamidah dan Mintohari. 2014. Penerapan Media Puzzle Untuk Meningkatkan Hasil Belajar Siswa Pada Pelajaran IPA. JPGSD. Volume 02 Nomor 01

Diana, A. 2013. Pengaruh Pembelajaran Kooperatif Tipe STAD Dengan Media Puzzle Terhadap Aktivitas Dan Hasil Belajar Siswa Kelas VIII Pada Materi Pokok Kubus Dan Balok SMPN 9 Mataram. Mataram. Tidak dipublikasikan.

Dimyati dan Mudjiono. 2009. Belajar dan Pembelajaran. Jakarta: Rineka Cipta.

Djumingin, S. 2011. Strategi dan aplikasi: model pembelajaran inovasif bahasa dan sastra. Makassar: Badan Penerbit UNM.

Hamalik, O. 2006. Media Pendidikan, Bandung: PT. Citra Aditya Bakti

Huda, M. 2009. Cooperative Learning Metode, Teknik, Struktur, dan Model Penerapan. Yogyakarta: Pustaka Pelajar.

Isjoni. 2010. Cooperative Learning Efektivitas Pembelajaran Kelempok. Bandung: Alfabeta

Kustandi dan Sutjipto. 2013. Media Pembelajaran. Bogor: Ghalia Indonesia

Kurniawati, dkk. 2013. Implementasi Metode Penugasan Analisis Video Pada Materi Pengembangan Kognitif, Sosial , Dan Moral. Jurnal Pendidikan IPA Indonesia. Volume 2 No.2.

Marwanto, dkk. 2014. Pengaruh Strategi Assurance Interest Assessment Satisfaction (Puzzle Vs Video) terhadap Hasil Belajajar Kognitif Siswa Tentang Ekosistem di Man 8 Jakarta. Jakarta: Tidak dipublikasikan.

Meltzer, D. 2002. The Relationship Between Mathematics Preparation and Conceptual Learning Gain in Physics: A Possible Hidden Variable in Diagnostic Pretest Scores. American Journal Physics, Volume 70 No. 2.

Muhson, A. 2010. Pengembangan Media Pembelajaran Berbasis Teknologi Informasi. Jurnal Pendidikan Akutansi Indonesia http://staff.uny.ac.id/sites/default/files/penelitian/ali-muhsonmpd/ali-muhson-2010-pengembangan-media.pdf. Vol. VIII. No. 2 - Tahun 2010, HIm. 1-10

Mulyasa, E. 2004. Kurikulum Berbasis Kompetensi, Konsep Karakteristik dan Impelemntasi. Bandung: Remaja Rosdakarya.

Patmonodewo, S. 2000. Pendidikan Anak Prasekolah. Jakarta: Rineka Cipta Bekerjasama dengan Departemen Pendidikan dan Kebudayaan.

Rahmanelli. 2008. Efektivitas Pemberian Tugas Media Puzzle dalam Pembelajaran Geografi Regional. Pelangi Pendidikan, Volume 11.

Resiyanti. 2010. Upaya Meningkatkan Kemampuan Membaca Peta Lingkungan Setempat dengan Media Puzzle Peta Pada Siswa Kelas IV SD Negeri 2 Petarukan Pemalang. Surakarta: Tidak dipublikasikan.

Rusman, dkk. 2010. Pembelajaran berbasis teknologi informasi dan komunikasi: mengembangkan profesionalitas guru. Jakarta: PT. Raja Grafindo Persada.

Sadiman, A. 2008. Media Pendidikan: Pengertian, Pengembangan, dan Pemanfaatannya. Jakarta: Rajawali Press.

Salwah, S. 2007, Permainan Educatif, Jakarta: Aq Press.

Sanjaya, W. 2008. Strategi pembelajaran berorientasi standar proses pendidikan. Jakarta: Prenada Media Group. 
Shifa. 2013. Pengembangan Alat Evaluasi Pembelajaran BertingkatBerdasarkan Taksonomi Bloom Untuk Mengetahui Kemampuan Berfikir Siswa Pada Tema Cahaya. Semarang: Tidak dipublikasikan.

Slameto. 2010. Belajar dan Faktor-Faktor yang Mempengaruhinya. Jakarta: Bina Aksara.

Received 25 June 2018

Accepted, 20 January 2019

\author{
Nurhaerani Samudar \\ Guru Bidang Studi IPA di SMPN 2 Mappedeceng Kab. Luwu Utara, dapat dihubungi melalui \\ pos-el: nurhaeranisam@gmail.com
}

\title{
Sudarto
}

\section{Ramlawati}

Dosen Prodi Pendidikan IPA Universitas Negeri Makassar, aktif meneliti di bidang pembelajaran IPA dan kimia, dapat dihubungi melalui pos-el ramlawati@unm.ac.id 